\title{
SUSTAINABLE PINEAPPLE FARM PLANNING BASED ON ECO- EFFICIENCY AND INCOME RISK: A COMPARISON OF CONVENTIONAL AND INTEGRATED FARMING SYSTEMS
}

\author{
Phrommarat, B. ${ }^{*}$ - OONKASEM, P. \\ Department of Environmental Science, Faculty of Science, Silpakorn University, \\ Nakhon Pathom 73000, Thailand \\ (phone: +66-3414-7005; fax: +66-414-7006) \\ *Corresponding author \\ e-mail:phrommarat_b@su.ac.th \\ (Received $2^{\text {nd }}$ Jan 2021; accepted $14^{\text {th }}$ May 2021)
}

\begin{abstract}
Considering the growing commitment of countries to sustainable agriculture, an integrated approach that considers environmental and economic performance or eco-efficiency (EE) was applied to compare two different farming systems of two pineapple cultivars, Nanglae and Phulae, produced in the northern region of Thailand. Environmental performance was assessed based on a life cycle approach. Thus, the total environmental load expressed as a single score was quantified and used as an environmental indicator of EE. Results showed that the integrated farming system of pineapple production was more sustainable than the conventional farming practice. The results of EE were then incorporated into a sustainable farm model to identify an optimal farm plan that corresponds to an objective function under available resources and constraints. In the model, income risk in terms of the variability of selling price was considered as a key factor in farmers' decision making. To maximize income and EE, the model suggested growing Phulae pineapple through integrated farming in an entire farm area to achieve the defined objective functions. However, considering risk, a new risk-efficient farm plan was recommended by replacing part of the area of the integrated Phulae with the integrated Nanglae. Diversification is an effective risk-reducing technique as a combination between the integrated Nanglae and integrated Phulae that have negative co-variances can help to stabilize farm income by lowering aggregate risk.
\end{abstract}

Keywords: life cycle assessment, eco-efficiency, sustainable farming, risk minimization, optimization

\section{Introduction}

Pineapple (Ananas comosus L. Merr.) is one of the most popular tropical fruits in the Bromeliaceae family; it is consumed worldwide as a fresh or processed product. Apart from its unique juicy taste, the fruit also contains a high level of vitamins and beneficial bioactive compounds such as ascorbic acid (vitamin $\mathrm{C}$ ), $\alpha$-carotene, $\beta$-carotene, phenolic compounds, ferric reducing antioxidant power and a protein-digesting enzyme called bromilain (Chiet et al., 2014; Ferreina et al., 2016). Among the major pineapple-producing countries, Thailand was the world's sixth largest pineapple producer in 2017, with a harvest of over 2,000 billion tons (FAOSTAT, 2020). In Thailand, different cultivars of pineapple are primarily grown in the northern, central, and southern regions. Chiang Rai, a northern province, is known as an important pineapple-producing source because two popular cultivars are planted in the area: Phulae and Nanglae. Phulae is a cultivar in the Queen group and Nanglae is in the Cayenne group (Popluechai et al., 2007). The key differences between two cultivars are that Nanglae is round and stout in shape with thin skin, while Phulae is smaller in size with thicker skin. In terms of taste, Nanglae's flesh is juicy and sweet while Phulae's is crunchy and aromatic. Therefore, the local pineapple producers are inevitably involved 
in decision-making on what cultivars should be produced under the defined timing and level of variable inputs such as land, machinery, agrochemicals, labor, and other capital resources. Most of the farmers make decisions based on profit-seeking behavior (Ramsden et al., 2017). Setting a clear idea on the objective function is important for farmers or decision makers to define the direction of the business and accordingly implement the most preferred action that is consistent with such an intended objective to achieve the ultimate goal. The objective of profit maximization is often used as a yardstick to measure the economic performance of a farm or business. However, Colman and Young (1989) argued that performance standards based on the assumption of profit maximization may not be applicable for some decision makers whose objective function involves elements other than profit. Recently, the objective of whole-farm decisionmaking has focused on a variety of issues other than profit, such as risk, social outcomes, and use of natural resources. Robertson et al. (2012) reviewed 53 cases of whole-farm modelling and concluded that $21 \%$ of studies on smallholder farmers in developing countries focused on food security maximization, while $21 \%$ of studies on industrialized countries considered profit with a certain measure of environmental impact. Therefore, decision-making in the management of agricultural resources is likely to be a complex process as the producer needs to account for competing demands, such as the need to protect the environment, the concern about risk, and the demand for sustainable production and cost saving (Kaiser and Messer, 2012).

To achieve sustainability in pineapple production, producers have to integrate three main elements: a healthy environment, economic profitability, and social benefits. Previously, assessing the sustainability of agricultural systems usually concentrated on quantifying environmental impacts such as greenhouse gas emissions, resource consumption, and the use of toxic chemicals. Life cycle assessment (LCA), an environmental management tool, is generally employed in identifying and quantifying material and energy usage and associated environmental impacts throughout a product's life cycle. Examples of LCA studies on the agricultural sector in Thailand are: an assessment of environmental impacts of Thai jasmine rice focusing on climate change, water use and biodiversity impacts (Mungkung et al., 2019), an evaluation of carbon footprint of pineapple production in central Thailand (Usubharatana and Phungrassami, 2017), and a study of LCA of pineapple production in northern Thailand (Oonkasem et al., 2019). An improved approach to assessing agricultural sustainability that incorporates environmental and economic performance, known as eco-efficiency (EE), has been introduced. The approach enables evaluation of whether the producers are using resources efficiently and minimizing environmental impact while still achieving their economic objectives (UNSCAP, 2009). EE is expressed as a ratio between economic value and environmental indicators; as a result, different options or strategies of production can be easily compared. Various EE studies on different agricultural products in Thailand have been conducted, such as on rain-fed and irrigated rice (Thanawong et al., 2014), para-rubber wood (Phungrassami and Usubharatana, 2015), and sugarcane as a part of biorefinery and ethanol production with a focus on greenhouse gas emissions (Silalertruksa et al., 2015). In addition, EE was used as a sustainable indicator when it was incorporated into a mathematic model to support decision making in supply chains (Carvalho et al., 2017). Liu et al. (2016) employed linear programming, a mathematical optimizing model, to facilitate the optimization of EE by focusing on the maximization of environmental improvement of a naphtha cracking plant based on the results of LCA. 
As agriculture is typically associated with management of either living plants or animals under the uncertain nature of factors such as weather conditions, disease, fluctuations of selling price, and cost of production factors that can directly affect economic profitability, it can be considered as a risky business. There are five main types of risk associated with the agricultural sector: production risk, price or market risk, financial risk, institutional risk and human risk (Komarek et al., 2020). Price or market risks that refer to the price variation of farm inputs and outputs are perceived as the most important in the agricultural sector (Meuwissen et al., 2001). Therefore, farmers as business operators have to make decisions responding to those risks efficiently based on their risk perceptions and attitudes. As reported by Hardaker et al. (2015), risk attitudes can be categorized into three main groups: risk aversion, risk indifference (or risk neutral), and risk preference. Evidently, most farmers are considered to be risk-averse as they do not usually want to be affected by a decision that would bring a high profit on average if that decision exposes them to a chance of lower income or loss in a particular year (Sulewski and Kłoczko-Gajewska, 2014). Mathematical programming methods are widely used to model farm production under risk. Markowitz (1959) used quadratic programming $(\mathrm{QP})$ in an empirical analysis of a stock portfolio problem. The QP formulation was subsequently applied in the agricultural context under the assumption that a farmer has preferences among alternative strategies based on their expected income and associated variance (E-V criterion). Hossain et al. (2002) used QP to assess risk associated with the current rice production in Dhaka, Bangladesh, and suggest more efficient plans to farmers. Effects of risk on risk-averse farmer's decision-making in Italy was examined by farm portfolio simulations based on QP and the linear approximation of the utility function through minimization of total absolute deviation (Rosa et al., 2019). The results affirmed the hypothesis that risk affects farmers' decisions and suggested that crop diversification is a promising strategy to lower risk.

Given the importance of pineapple farming in Thailand and growing concerns about sustainability, environmental impacts, and economic profitability and stability, this study aims to create an integrated framework to understand the interactions between the economic performance and associated environmental impacts of pineapple production systems in a northern province of Thailand. Two alternative cultivars of pineapple produced by two different farming practices, namely, conventional and integrated practices, were compared and considered in the sustainable farm planning model. The sustainable farm planning model consisted of two main elements to suggest a set of efficient solutions showing trade-off among profit, EE, and risk. First, EE as a measure of sustainability that links economic performance with environmental impacts was assessed. The environmental impacts of the pineapple production were analyzed based on the life cycle approach, and the economic values related to farm inputs and outputs were identified. Second, to assist in the decision making of famers under risk, we considered the variation of selling price. We applied QP, a modelling technique that seeks to minimize risk for different levels of expected profit.

\section{Material and Method}

\section{Study area description}

Nanglae sub-district is located north of Muang district in Chiang Rai, the northernmost province of Thailand (latitude 19 $19^{\circ} 53^{\prime} 40^{\prime \prime}$ to $20^{\circ} 07^{\prime} 10^{\prime \prime} \mathrm{N}$, longitude $99^{\circ} 45^{\prime} 51^{\prime \prime}$ to $99^{\circ} 57^{\prime} 24^{\prime \prime}$ E) as shown in Figure 1. The western part of the sub-district is 
the high terrain while the eastern part is characterized by relatively low plains suitable for agriculture. The average elevation of the area is $580 \mathrm{~m}$ above sea level, ranging between $380 \mathrm{~m}$ to $1,070 \mathrm{~m}$. The area is exposed to a tropical climate with two distinct seasons: dry season from November to April and wet season from May to October. The average temperature is $24.6^{\circ} \mathrm{C}$ and the annual average rainfall is $1,737 \mathrm{~mm}$. Of the total area of 5,500 ha, 2,429 ha is occupied for agricultural activities while the area of pineapple cultivation is approximately 760 ha (Suk-ueng et al., 2019). Nanglae is known for producing high-quality pineapple cultivars, particularly Nanglae pineapple, which is named after the area of cultivation. In addition, a hybrid cultivar between Nanglae and Phuket pineapple or Phulae is also extensively cultivated in the area. A survey was conducted on 8 major local pineapple producers who occupied over 5 ha of land in Nanglae sub-district, Chiang Rai province, in the northern region of Thailand.
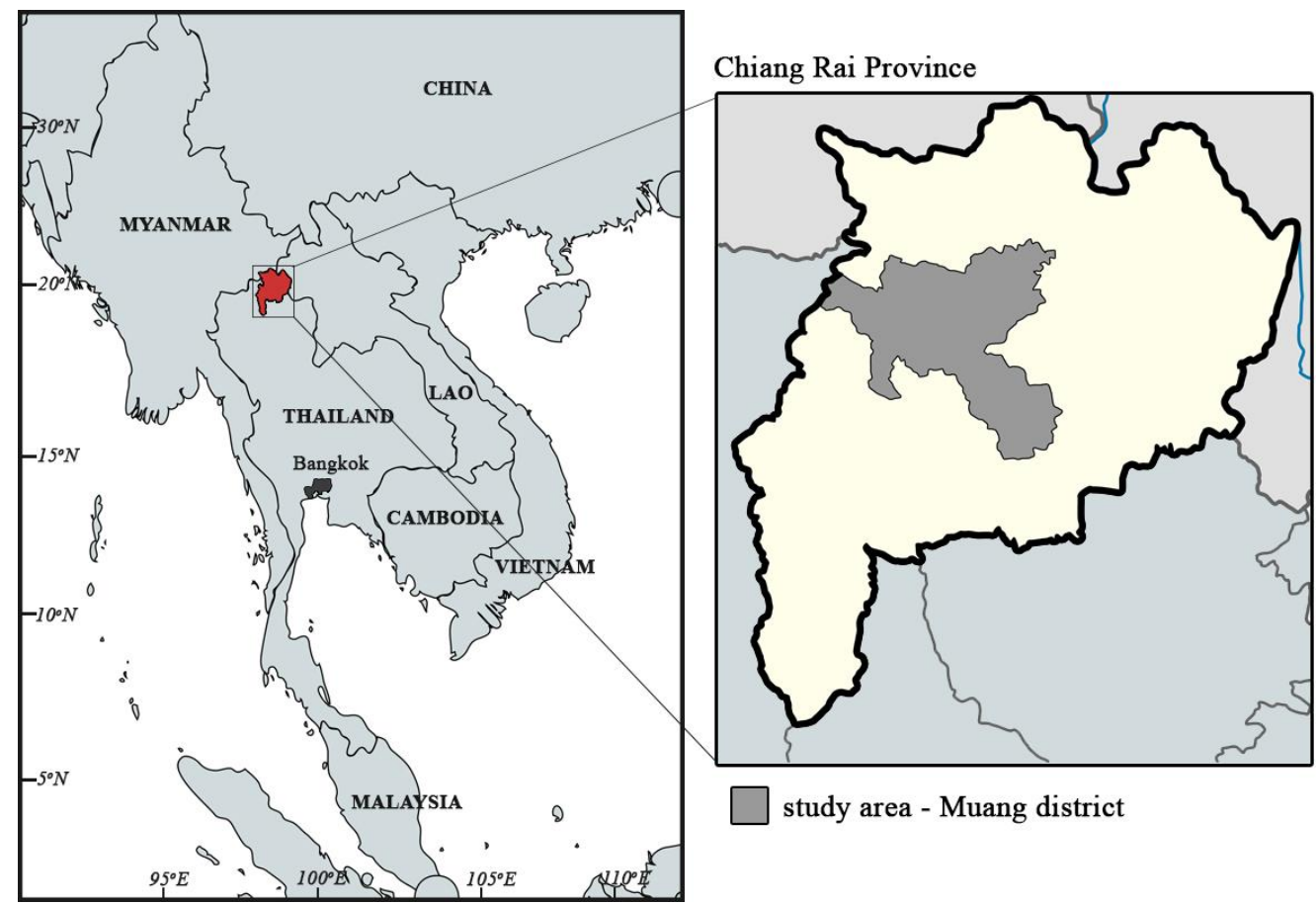

Figure 1. Geographical location of the study area

\section{Pineapple farming system}

Pineapple is considered to be a key cash crop in Nanglae sub-district because of its unique taste compared with pineapple produced in other regions. Two cultivars typically grown in the area: Nanglae and Phulae. Nanglae, which is a pinneapple cultivar in the Cayenne group, has a sweet taste, smooth texture, thin skin, and round shape. Phulae, a cultivar in the Queen group, has thicker skin and a crunchy texture. In terms of cultivation, Phulae can be harvested twice a year while Nanglae can be harvested once a year during a certain period (approximately November to March) to yield the best quality of the product. The cultivation is undertaken under a rain-fed system. However, each cultivar requires different farm inputs in production activities such as land, fertilizer, pesticide, machinery, and labor (as summarized in Table 1). Therefore, local farmers have to make decisions on how much of each cultivar to produce under available resources. 
Phrommarat - Oonkasem: Sustainable pineapple farm planning based on eco-efficiency and income risk: a comparison of conventional and integrated farming systems $-2705-$

Table 1. Input and output parameters of pineapple production systems per ha

\begin{tabular}{|c|c|c|c|c|c|}
\hline & Unit & Con $\mathrm{NL}^{\mathrm{a}}$ & Int $\mathbf{N L}^{\mathrm{b}}$ & Con $\mathbf{P L}^{\mathrm{c}}$ & Int PL ${ }^{\mathrm{d}}$ \\
\hline \multicolumn{6}{|l|}{ INPUTS } \\
\hline Tillage & ha & 1 & 1 & 1 & 1 \\
\hline Mowing & ha & 1 & 2 & 1 & 2 \\
\hline Glyphosate & $\mathrm{g}(\mathrm{AI})^{\mathrm{e}}$ & 1800 & 0 & 1800 & 0 \\
\hline Transportation & $\mathrm{km}$ & 10 & 10 & 10 & 10 \\
\hline Fosetyl-Al & $\mathrm{g}(\mathrm{AI})^{\mathrm{e}}$ & 500 & 0 & 500 & 0 \\
\hline \multicolumn{6}{|l|}{ Fertilizers } \\
\hline N-Fertilizer (Urea) & $\operatorname{kg~N}$ & 143.8 & 126.6 & 143.8 & 126.6 \\
\hline $\mathrm{N}$-Fertilizer $(\mathrm{AP})^{\mathrm{f}}$ & $\mathrm{kg} \mathrm{N}$ & 50.0 & 47.6 & 50.0 & 47.6 \\
\hline P-Fertilizer & $\mathrm{kg} \mathrm{P}_{2} \mathrm{O}_{5}$ & 62.5 & 59.4 & 62.5 & 59.4 \\
\hline K-Fertilizer & $\mathrm{kg} \mathrm{K}_{2} \mathrm{O}$ & 0 & 0 & 0 & 0 \\
\hline Effective microbes & 1 & 0 & 109.0 & 0 & 109.0 \\
\hline \multicolumn{6}{|l|}{ OUTPUTS } \\
\hline Crop residue & $\mathrm{kg}$ & 1089.6 & 0.0 & 1089.6 & 0.0 \\
\hline Fresh pineapple & $\mathrm{kg}$ & 12,500 & 10,275 & $6250 / 7500^{g}$ & $5138 / 6165^{\mathrm{g}}$ \\
\hline
\end{tabular}

Note: ${ }^{\mathrm{a}}$ conventional Nanglae; ${ }^{\mathrm{b}}$ integrated Nanglae; ${ }^{\mathrm{c}}$ conventional Phulae; ${ }^{\mathrm{d}}$ integrated Phulae; ${ }^{\mathrm{e}}$ gram of active ingredient; ${ }^{\mathrm{f}}$ Ammonium phosphate fertilizer (16-20-0); ${ }^{\mathrm{g}}$ yield of the first season/yield of the second season

\section{Environmental assessment of pineapple farming}

Environmental impact assessment of pineapple farming was conducted using life cycle assessment (LCA). An LCA framework based on ISO14040 (2006) and ISO14044 (2006) consists of four main phases: goal and scope definition, life-cycle inventory (LCI) analysis, life-cycle impact assessment (LCIA), and interpretation of the results. In the current study, the aim of the LCA was to quantify environmental impacts on a per-hectare basis (functional unit) associated with the production of two cultivars of pineapple considered in the farm system as described above. The results were subsequently used to identify EE for each pineapple cultivar and incorporated into the sustainable farm model. The system boundary for the LCA covering all the relevant inputs and processes in fresh pineapple production from land preparation to harvesting or under a cradle-to-farm-gate boundary is depicted in Figure 2. However, farm buildings such as storehouses and sheds were excluded from the system boundary due to their long lifetime coupled with inadequate data. Inventory analysis and impact assessment were modeled by OpenLCA software version 1.8 (Greendelta, 2018) along with the LCI database, Ecoinvent 3.3. The environmental impact assessment method adopted in the analysis was ReCiPe (Goedkoop et al., 2013).

In the LCI analysis, a collection of data (primary data) on farm inputs, transportation, energy consumption, and environmental emissions related to each process within the system boundary was undertaken during the cultivation year 2019. On the other hand, secondary data associated with background processes such as production of fertilizers, fuel, machinery, and pesticides were obtained from the LCI database, Ecoinvent 3.3. All relevant parameters in each process are illustrated in Table 1. Sources of secondary data or assumptions used in the analysis were summarized in Table 2. Acquisition of data and assumptions used in the analysis of each life-cycle stage are described as follows. 


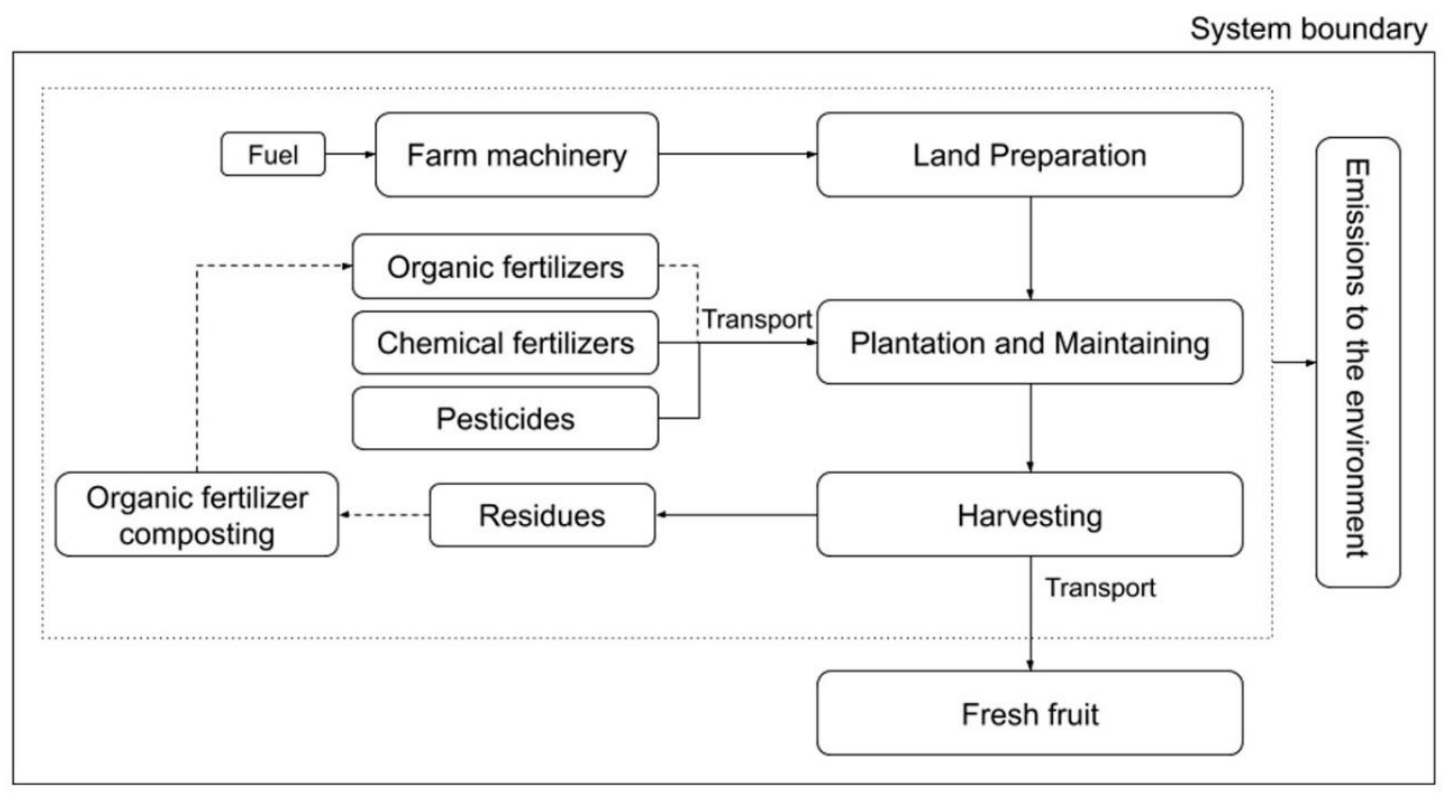

$\rightarrow$ Flows in Conventional and Integrated farming systems

$\rightarrow$ Flows in Integrated farming system

Figure 2. System boundary of Phulae and Nanglae pineapple production systems

Table 2. Sources of secondary data or assumptions used in the analysis

\begin{tabular}{c|c}
\hline Data/Assumption & Source \\
\hline $\begin{array}{c}\text { Production of farm inputs (e.g. fertilizers, pesticides, machinery, } \\
\text { equipment and fuel) }\end{array}$ & Ecoinvent 3.3 database \\
Production of organic fertilizer from composted pineapple residues & $\begin{array}{c}\text { Department of Agriculture (2015) } \\
\text { Yields of intergrated farming } \\
\text { Transportation }\end{array}$ \\
\hline
\end{tabular}

\section{Land preparation}

To prepare land for pineapple cultivation, land was ploughed and made to a fine tilth by a power tiller. After tillage, an herbicide (glyphosate) was applied to control weed before plantation in conventional farming practice. The land was then dug and levelled to make trenches manually. All machines used were fueled by diesel. Environmental emissions associated with this stage included air emissions caused by the combustion of machines and soil contamination from the use of herbicide.

\section{Plantation and maintenance}

Most of the local farmers in the area propagate pineapple crops by using suckers. Planting was conducted in double rows at planting densities ranging from 50,000 to 70,000 plants per hectare. In conventional farming practice, chemical fertilizers such as urea (46-0-0) and ammonium phosphate (16-20-0) were applied to provide essential nutrients for the crops. However, in the integrated (partly organic) farming practice, crop residues (mainly leaves) from harvesting in the previous season were composted 
with poultry manure and a small quantity of urea (to supply additional nitrogen for microorganisms) according to the Department of Agriculture (2015). An experiment on pineapple residue compost was conducted to analyze macro-nutrient content in organic fertilizer. In this study, we assumed that the organic fertilizer was applied on the field to compensate chemical fertilizers, which were still used to fulfill the remaining nutrient requirements. During the plantation period, weed control was undertaken by a backpack mower, once for the conventional farming practice and twice for the integrated farming practice. Glyphosate was applied during the fruiting period in the conventional farming method. An organophosphate fungicide, fosetyl-aluminum, was used to prevent fungiassociated diseases such as heart rot, root rot, and fruit core rot in the conventional system. Rainwater was the principal source of water in the cultivation, which was assumed to have no environmental impact. Therefore, it was excluded from the environmental inventory.

\section{Harvesting}

After being planted, Nanglae pineapple takes 12-14 months to produce fruit, whereas Phulae requires only 4-6 months. Fruit yields per hectare of both Nanglae and Phulae from conventional farming were acquired from the survey. Yields of integrated farming were assumed based on the work of Darnaudery et al. (2018) that fruit yields of pineapples grown by integrated farming practice were $5.4 \%$ lower than those grown by conventional farming. However, the quality of fruits produced by integrated farming tends to be higher and sold at a $15 \%$ higher in price than that produced by conventional farming (Kleeman, 2011). Human labor was employed to harvest ripe fruits. After harvesting, the products were transported to adjacent local buyers by a pick-up or small truck. The distance between the farm and the buyer was assumed to be $10 \mathrm{~km}$.

\section{Eco-efficiency assessment}

Eco-efficiency (EE) is an approach to evaluate sustainability at the farm level by considering whether farmers are efficiently utilizing resources and minimizing environmental impacts while achieving their economic goals. The EE assessment of a product or service was expressed as a ratio between economic value and environmental indicator in which different options or strategies of production can be easily compared. The environmental impact indicator was a single score (endpoint environmental damage) evaluated by the aforementioned LCA framework. The economic performance indicator was determined based on farm income in the form of total gross margin (TGM). TGM is a measure of financial performance of farm-level activities incorporating gross margins, that is, the difference between total revenue and total flow input costs (Rae, 1994). Nonetheless, only variable costs or costs related to farm inputs (e.g., fertilizer, pesticide, and fuel), labor, pineapple crown, and service machine were considered while fixed costs such as depreciation, interest, and tax were excluded. Monetary value of all economic indicators was expressed in the local currency (Thai baht). Tables 3 and 4 show the gross margins of different cultivars of pineapple grown under two production systems considered in the current study and their components. Gross margin of each type of pineapple production was calculated based on annual average data on cost of production and selling price for 9 years (2011-2019). The gross margins were adjusted by the inflation rate into the reference year (2019) value. 
Table 3. Gross margins and their components of different cultivars of pineapple grown under the conventional production system (per ha)

\begin{tabular}{c|c|c|c|c|c}
\hline List & Unit & Con NL & Con PL1 & Con PL2 & Cost (THB)/unit \\
\hline Sucker & unit & 25000 & 25000 & 25000 & 2.5 \\
Fertilizer - Urea & $50 \mathrm{~kg}$-sack & 6.25 & 6.25 & 6.25 & 600 \\
Fertilizer - 16-20-0 & $50 \mathrm{~kg}$-sack & 6.25 & 6.25 & 6.25 & 650 \\
Land preparation (service) & ha & 1.00 & 1.00 & 1.00 & 4375 \\
Herbicide - Glyphosate & $11-$-Bottle & 3.75 & 3.75 & 3.75 & 300 \\
Fungicide - Fosetyl-Al & $\mathrm{g}$ & 500.00 & 500.00 & 500.00 & 0.9375 \\
Maintenance (labor) & man-day & 43.75 & 12.50 & 12.50 & 300 \\
Harvesting (labor) & man-day & 62.50 & 62.50 & 62.50 & 300 \\
\hline Total cost & THB & 108156.25 & 98781.25 & 98781.25 & \\
Yield & kg & 12500.0 & 6250.0 & 7500.0 & \\
Selling price & THB & 13.09 & 22.27 & 23.59 & \\
Total Revenue & THB & 163571.43 & 139196.43 & 176892.86 & \\
\hline Gross Margin & THB & $\mathbf{5 5 4 1 5 . 1 8}$ & $\mathbf{4 0 4 1 5 . 1 8}$ & $\mathbf{7 8 1 1 1 . 6 1}$ & \\
\hline
\end{tabular}

Note: PL1 and PL2 refer to the harvesting seasons

Table 4. Gross margins and their components of different cultivars of pineapple grown under the integrated production system (per ha)

\begin{tabular}{c|c|c|c|c|c}
\hline List & Unit & Int NL & Int PL1 & Int PL2 & Cost (THB)/unit \\
\hline Sucker & unit & 25000 & 25000 & 25000 & 2.5 \\
Fertilizer - Urea & $50 \mathrm{~kg}$-sack & 5.50 & 5.50 & 5.50 & 600 \\
Fertilizer - 16-20-0 & $50 \mathrm{~kg}$-sack & 5.94 & 5.94 & 5.94 & 650 \\
Land preparation (service) & ha & 1.00 & 1.00 & 1.00 & 4375 \\
Herbicide - Glyphosate & $11-$-Bottle & 0.00 & 0.00 & 0.00 & 300 \\
Fungicide - Fosetyl-Al & g & 0.00 & 0.00 & 0.00 & 0.9375 \\
Maintenance (labor) & man-day & 56.25 & 25.00 & 25.00 & 300 \\
Harvesting (labor) & man-day & 62.50 & 62.50 & 62.50 & 300 \\
\hline Total cost & THB & 109665.31 & 100290.31 & 100290.31 & \\
Yield & kg & 11825.0 & 5912.5 & 7095.0 & \\
Selling price & THB & 15.05 & 25.61 & 27.12 & \\
Total Revenue & THB & 177949.36 & 151431.79 & 192441.74 & \\
\hline Gross Margin & THB & $\mathbf{6 8 2 8 4 . 0 4}$ & $\mathbf{5 1 1 4 1 . 4 8}$ & $\mathbf{9 2 1 5 1 . 4 3}$ & \\
\hline
\end{tabular}

Note: PL1 and PL2 refer to the harvesting seasons

\section{Sustainable farm model}

The sustainable farm model (SFM) was established by considering economic and environmental dimensions. The model consisted of three core components: EE for each production activity incorporating the gross margins and environmental indicators (from LCA), farm-level linear programming (LP) model including associated input-output parameters (e.g., labor, machinery, and crop yields), and constraints (e.g., land, labor, and capital), and finally, the variability of income or risk corresponding with suggested farm plans. The risk assessment was conducted subject to the key assumptions that 
farmer's preferences among alternative plans are based on expected income (E) and associated income variance $(\mathrm{V})$. The main criterion is to treat variability of gross margin in the objective function by minimizing variances or co-variances for all expected incomes on the feasible range of the LP model solution.

A non-linear method known as quadratic risk programming (QRP) was employed in an attempt to obtain an $\mathrm{E}-\mathrm{V}$ frontier that displays a set of efficient farm plans to allow the farmer to manage tradeoffs between income and its variability or risk. For simplicity, we assumed that variances/co-variances of selling prices represent income risk. According to Hazell and Norton (1986), the notation of variances/co-variances of the total gross margin is as follows (Eq.1):

$$
V=\sum_{j} \sum_{k} x_{j} x_{x} \delta_{j k}
$$

where $x_{j}$ defines the level of $j^{\text {th }}$ activity, $x_{k}$ the level of $k^{\text {th }}$ activity, $\delta_{j k}$ the variance of gross margins (GMs) when $j=k$ and co-variance of GMs between $j^{\text {th }}$ and $k^{\text {th }}$ activity.

The variance of total gross margin is a summary of the variability of each activity gross margin as shown in Eq. 1. To derive the E-V frontier that depicts the tradeoff of efficient farm plans, we incorporate the variances and co-variances into the LP model. The new objective function is then set to minimize risk in the form of an aggregation of variance/co-variance for a given level of income. Therefore,

$$
\operatorname{Min} V=\sum_{j} \sum_{k} x_{j} x_{x} \delta_{j k}
$$

such that

$$
\begin{gathered}
\sum_{j} \bar{c}_{j} x_{j}=\lambda, \\
\sum_{j} a_{i j} x_{j} \leq b_{i}, \text { for all } i,
\end{gathered}
$$

and

$$
x_{j} \geq 0, \text { for all } j,
$$

where $\bar{c}_{j}$ denotes the expected gross margin per unit of the $\mathrm{j}^{\text {th }}$ activity, and $\lambda$ is a scalar parameter that denotes the aggregation of the expected income. As the term $x^{2} \delta_{j k}$ appears when $j=k$, we have a quadratic function. The solving program for this problem becomes one of non-linear programming or QRP rather than linear programming (Anderson and Dillon, 1992). A set of solutions was derived from varying $\lambda$ over the feasible range that increases total gross margin and variance until reaching the maximum point of the total gross margin subject to constraints in Eqs. 4 and 5 in agreement with the linear programming optimizing problem.

Three different objective functions were investigated to assess alternative farm plans where farmers can make a decision based on their preferences. In the first scenario, we assumed that the most preferable farm plan for the farmer was the most profitable one; thus, the objective function was to maximize the total gross margin. For the second scenario, we assumed that the farmer was encouraged to perform more environmentally friendly practices on their farm. The objective function was set to find the optimal farm 
plan under the maximum EE, seeking a balance between economic and environmental perspectives. Finally, the objective function of the third scenario was to minimize risk. As a tradeoff between profit loss and risk reduction occurred, the target income was reduced by $1 \%, 2 \%$, and $3 \%$ from the income maximizing scenario $(\lambda)$ to allow the model to find a risk-minimizing farm plan. All related parameters were recorded for each scenario, including total gross margin, total environmental impact score, EE, and total income risk.

\section{Results and Discussion}

\section{LCA of pineapple farming}

LCA results of monocropping of Nanglae and Phulae pineapples were conducted based on ReCiPe endpoint (hierarchist) method normalized and weighted by an average world environmental impact for the year 2000 (World ReCiPe H/H, 2000). The results were presented in two parts: midpoint results presenting characterization and damage assessment indicators and endpoint results showing the weighted indicators. Table 5 illustrates the impact results of 17 characterization indicators of the two cultivars under two different farming practices (of both cultivars). The comparisons were based on the same functional unit, farming activities in one hectare of land.

Table 5. Life cycle impact assessment results of midpoint indicators of the two production systems

\begin{tabular}{c|c|c|c|c}
\hline Impact category & $\begin{array}{c}\text { Damage } \\
\text { category }\end{array}$ & Unit & $\begin{array}{c}\text { Conventional } \\
\text { system }\end{array}$ & $\begin{array}{c}\text { Integrated } \\
\text { system }\end{array}$ \\
\hline Agricultural land occupation (ALO) & Ecosystems & species.yr & $1.98 \mathrm{E}-04$ & $1.97 \mathrm{E}-04$ \\
Climate change (CC) & Ecosystems & species.yr & $8.02 \mathrm{E}-06$ & $5.88 \mathrm{E}-06$ \\
Freshwater ecotoxicity (FET) & Ecosystems & species.yr & $6.67 \mathrm{E}-09$ & $5.83 \mathrm{E}-09$ \\
Freshwater eutrophication (FE) & Ecosystems & species.yr & $1.21 \mathrm{E}-08$ & $9.83 \mathrm{E}-09$ \\
Marine ecotoxicity (MET) & Ecosystems & species.yr & $1.42 \mathrm{E}-09$ & $1.25 \mathrm{E}-09$ \\
Natural land transformation (NLT) & Ecosystems & species.yr & $6.03 \mathrm{E}-07$ & $5.46 \mathrm{E}-07$ \\
Terrestrial acidification (TA) & Ecosystems & species.yr & $3.96 \mathrm{E}-08$ & $2.78 \mathrm{E}-08$ \\
Terrestrial ecotoxicity (TET) & Ecosystems & species.yr & $2.35 \mathrm{E}-08$ & $2.05 \mathrm{E}-08$ \\
Urban land occupation (ULO) & Ecosystems & species.yr & $1.76 \mathrm{E}-07$ & $1.65 \mathrm{E}-07$ \\
Climate change (CC) & Human health & DALYa & $1.42 \mathrm{E}-03$ & $1.04 \mathrm{E}-03$ \\
Human toxicity (HT) & Human health & DALY & $2.27 \mathrm{E}-04$ & $2.08 \mathrm{E}-04$ \\
Ionising radiation (IR) & Human health & DALY & $1.20 \mathrm{E}-06$ & $1.04 \mathrm{E}-06$ \\
Ozone depletion (OD) & Human health & DALY & $3.58 \mathrm{E}-07$ & $3.12 \mathrm{E}-07$ \\
Particulate matter formation (PMF) & Human health & DALY & $6.95 \mathrm{E}-04$ & $5.78 \mathrm{E}-04$ \\
Photochemical ozone formation (POF) & Human health & DALY & $1.61 \mathrm{E}-07$ & $1.45 \mathrm{E}-07$ \\
Fossil depletion (FD) & Resources & USD & $5.08 \mathrm{E}+01$ & $4.54 \mathrm{E}+01$ \\
Metal depletion (MD) & Resources & USD & $4.36 \mathrm{E}+00$ & $4.05 \mathrm{E}+00$ \\
\hline
\end{tabular}

Note: a disability-adjusted life year unit

Apart from the impact on agricultural land occupation (ALO), the conventional farming practice showed higher impact values in all midpoint categories than the 
organic farming. In the comparisons, the impact on terrestrial acidification (TA) displayed the largest difference between the two farming practices $(30 \%)$ followed by the impact on climate change (CC) $(27 \%)$. The contributions of the various processes to the midpoint impacts in the two different farming practices were depicted in Figure 3, which shows that the differences were due to the reduction of chemical fertilizers used in the field coupled with the utilization of residues instead of being treated as waste in the integrated farming.

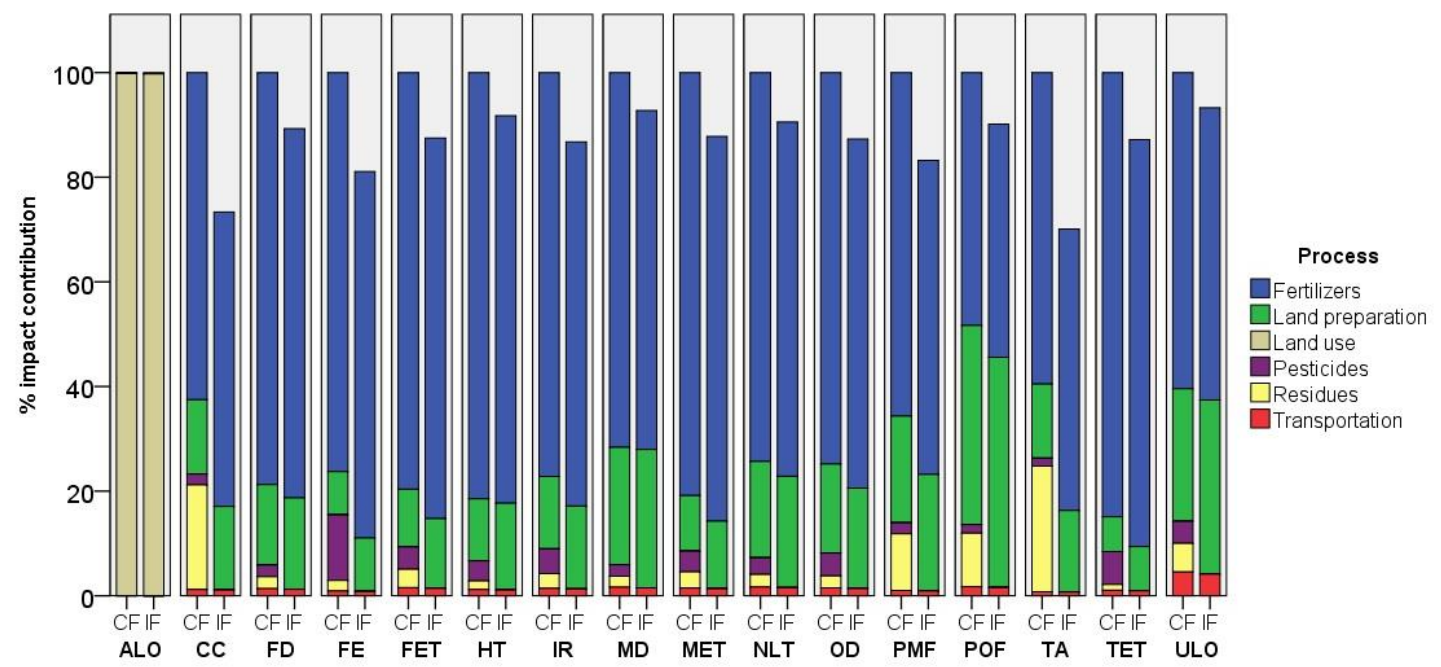

Figure 3. Contributions of the various processes to the midpoint impacts in the two different farming practices $(A L O=$ agricultural land occupation, $C C=$ climate change, $F D=$ fossil depletion, $F E=$ freshwater eutrophication, FET = freshwater ecotoxicity, $H T=$ human toxicity, $I R=$ ionizing radiation, $M D=$ metal depletion, $M E T=$ marine ecotoxicity, $N L T=$ natural land transformation, $O D=$ ozone depletion, $P M F=$ particulate matter formation, $P O F=$ photochemical ozone formation, $T A=$ terrestrial acidification, $T E T=$ terrestrial ecotoxicity and $U L O=$ urban land occupation)

According to the experiment and nutrient analysis, organic fertilizer from composted pineapple leaves contained $26.7 \mathrm{~g} / \mathrm{kg}(19.6 \mathrm{~kg} / \mathrm{ha})$ of nitrogen, $4.9 \mathrm{~g} / \mathrm{kg}(3.1 \mathrm{~kg} / \mathrm{ha})$ of phosphate, and $17.3 \mathrm{~g} / \mathrm{kg}(12.7 \mathrm{~kg} / \mathrm{ha})$ of potash that can compensate chemical fertilizers to meet the recommended dose of fertilizer for pineapple and reduce the consequent impact of chemical fertilizer production on the environment. From a process perspective, the production of chemical fertilizers, particularly N-fertilizer, was the key contributor to all the impacts in farming practices, except the ALO, which was solely caused by agricultural land use. Therefore, the integrated farming system that utilized a lower amount of chemical fertilizers and pesticides showed higher environmental benefits. In terms of the endpoint assessment, the results represented as an environmental single score $(\mathrm{Pt})$ indicated that the integrated farming had a $10 \%$ lower score than the conventional practice, as shown in Table 5. The total scores that were subsequently used as the environmental indicators in the SFM were 5.20E-08 and 4.73E-08 Pt for the conventional and integrated practices, respectively. 


\section{Sustainable farm planning}

The results of sustainable farm planning are presented in Tables 6 and 7. The analysis (SC1) was initially undertaken, adhering to the objective function of the basic farm-level LP model, that is, to maximize annual farm income in terms of total gross margin (TGM). Thus, variances/co-variances of the selling prices and environmental impact indicators directly varied due to changes in activity level indicated by the LP solutions. The solution suggested that the optimal farm plan was to grow the integrated Phulae pineapple in the entire area ( 8 ha of land) that can be harvested in the two consecutive seasons. This farm plan was also the optimal solution for the second scenario in which the objective function was set to maximize EE of the production. By considering the aggregation of the ratio between TGM and the environmental impact score, the results showed that high net profit coupled with low environmental impact indicator of the integrated farming led to maximal EE. However, this farm plan involved the highest income risk among other farm plans.

Table 6. Results of associated indicators and optimal farm plans from the sustainable farm modelling in scenarios 1 and 2

\begin{tabular}{|c|c|c|c|}
\hline & & \multicolumn{2}{|c|}{ Objective function } \\
\hline & & SC1-Max TGM & SC2-Max EE \\
\hline \multirow{4}{*}{ Indicator } & TGM (THB) & 1146343 & 1146343 \\
\hline & Single Score $(\mathrm{Pt})$ & 7.57E-07 & $7.57 \mathrm{E}-07$ \\
\hline & Risk $\left(\mathrm{THB}^{2}\right)$ & 1293.7 & 1293.7 \\
\hline & $\mathrm{EE}(\mathrm{THB} / \mathrm{Pt})$ & $2.42 \mathrm{E}+13$ & $2.42 \mathrm{E}+13$ \\
\hline \multirow{6}{*}{$\begin{array}{l}\text { Farm Plan } \\
\text { (ha of crop) }\end{array}$} & Con NL & 0.00 & 0.00 \\
\hline & Int NL & 0.00 & 0.00 \\
\hline & Con PL1 & 0.00 & 0.00 \\
\hline & Int PL1 & 8.00 & 8.00 \\
\hline & Con PL2 & 0.00 & 0.00 \\
\hline & Int PL2 & 8.00 & 8.00 \\
\hline
\end{tabular}

Note: Scenario 1 - income (total gross margin; TGM) maximizing scenario (SC1-Max TGM); Scenario 2 - eco-efficiency maximizing scenario (SC2-Max EE); conventional farming Nanglae (Con NL); integrated farming Nanglae (Int NL); conventional farming Phulae (Con PL); integrated farming Phulae (Int PL); numbers after PL denote harvesting seasons

In terms of risk-minimizing farm plans, the results from the QRP incorporated the variances and co-variances of the selling price into the LP model. Although the integrated practice of Phulae can generate high income and EE, it also has a high level of income uncertainty due to the volatility of selling prices, especially in the first season, as shown in Table 8. Reducing the expected income by $1 \%$ from the TGM maximizing scenario (SC3) contributed a $4.7 \%$ reduction in income risk. To lessen the risk, the previous income-maximizing farm plan was diversified. The model opted to slightly lessen the area of the integrated Phulae and instead, produce integrated Nanglae as it has negative co-variances in price with integrated Phulae in the two seasons. The new farm plan suggested to grow 0.15 ha of Nanglae through the integrated practice and reduce the area of integrated Phulae to 7.85 ha. A further reduction of expected income by $1 \%$ (SC4) further decreased the risk from the previous scenario by $4.6 \%$. The area of 
conventional Nanglae was suggested to increase to 0.31 ha, whereas the area of integrated Phulae was lowered to 7.69 ha in both seasons. Finally, when the expected income was set at a $3 \%$ reduction, the risk was further reduced by $4.4 \%$ and the area of conventional Nanglae production was expanded to 0.46 ha. The area of integrated Phulae was restricted to 7.54 ha. According to the three risk-minimizing farm plans, SC3 was regarded as the most risk-efficient farm plan for risk-averse farmers because it showed the largest risk reduction when the expected income was set to lessen by $1 \%$.

Table 7. Results of associated indicators and optimal farm plans from the sustainable farm modelling in scenarios 3,4 and 5

\begin{tabular}{c|c|c|c|c}
\hline \multicolumn{2}{c|}{} & \multicolumn{3}{|c}{ Objective function } \\
\cline { 3 - 5 } \multicolumn{1}{c|}{} & $\begin{array}{c}\text { SC3-Min Risk } \\
\text { (maxTGM -1\%) }\end{array}$ & $\begin{array}{c}\text { SC4-Min Risk } \\
\text { (maxTGM -2\%) }\end{array}$ & $\begin{array}{c}\text { SC5-Min Risk } \\
\text { (maxTGM -3\%) }\end{array}$ \\
\hline \multirow{4}{*}{ Indicator } & TGM (THB) & 1134880 & 1123416 & 1111953 \\
& Single Score (Pt) & $7.49 \mathrm{E}-07$ & $7.42 \mathrm{E}-07$ & $7.35 \mathrm{E}-07$ \\
& Risk (THB $\left.{ }^{2}\right)$ & 1233.0 & 1174.0 & 1116.8 \\
& EE (THB/Pt) & $2.40 \mathrm{E}+13$ & $2.38 \mathrm{E}+13$ & $2.35 \mathrm{E}+13$ \\
\hline \multirow{3}{*}{ Farm Plan } & Con NL & 0.00 & 0.00 & 0.00 \\
& Int NL & 0.15 & 0.31 & 0.46 \\
& Con PL1 & 0.00 & 0.00 & 0.00 \\
& Int PL1 & 7.85 & 7.69 & 7.54 \\
& Con PL2 & 0.00 & 0.00 & 0.00 \\
& Int PL2 & 7.85 & 7.69 & 7.54 \\
\hline
\end{tabular}

Note: Scenario 3 - risk minimization at 1\% TGM reduction (from SC1); Scenario 4 - risk minimization at $2 \%$ TGM reduction; Scenario 5 - risk minimization at 3\% TGM reduction; conventional farming Nanglae (Con NL); integrated farming Nanglae (Int NL); conventional farming Phulae (Con PL); integrated farming Phulae (Int PL); numbers after PL denote harvesting seasons

Table 8. Variance/covariance matrix of selling prices of pineapple products based on 8-year statistical data (2011-2019) $\left(T H B^{2}\right)$

\begin{tabular}{c|c|c|c|c|c|c}
\hline & Con NL & Int NL & Con PL1 & Int PL1 & Con PL2 & Int PL2 \\
\hline Con NL & 5.776 & & & & & \\
Int NL & 6.642 & 7.638 & & & & \\
Con PL1 & -2.013 & -2.315 & 4.991 & & & \\
Int PL1 & -2.315 & -2.663 & 5.739 & 6.600 & & \\
Con PL2 & -1.764 & -2.029 & 3.030 & 3.484 & 4.236 & \\
Int PL2 & -2.029 & -2.334 & 3.484 & 4.007 & 4.871 & 5.601 \\
\hline
\end{tabular}

Note: conventional farming Nanglae (Con NL); integrated farming Nanglae (Int NL); conventional farming Phulae (Con PL); integrated farming Phulae (Int PL); numbers after PL denote harvesting seasons

The overall results indicated that the production of Phulae pineapples by integration farming practice is likely to be the optimal farm plan for the farmers who seek to maximize income and, simultaneously, achieve a high level of EE. For the local farmers, Phulae tends to be more attractive than Nanglae because the cultivar can be 
harvested twice a year. Although the selling price of Phulae products in the first season is slightly lower than that in the second season due to its lower quality of taste, an aggregate of income during two seasons is substantially higher than growing Nanglae. In addition, the market demand of Phulae pineapples for local supermarkets and exporting to neighboring countries is high while the products are in short supply. This market mechanism attracts the local farmers to shift to Phulae rather than Nanglae production. Nonetheless, according to a sensitivity analysis of the TGM maximizing model, the optimal solution would change to the conventional Phulae if TGM of the integrated Phulae decreases (or TGM of the conventional Phulae increases) by THB 10,726 and THB 14,040 in the first and second seasons, respectively. The new solution can also occur when the selling price of the integrated Phulae decreases by approximately $7.2 \%$, assuming unchanged total production cost and fruit yield. In addition, the integrated Nanglae would be a preferable choice if its TGM increases by THB 75,009.

Various observations can be obtained from the QRP results. First, the results revealed the scope of tradeoffs between expected income and its variance, that is, to gain a higher expected income, the farmer has to experience a higher level of risk. Moreover, the cost of tradeoff appeared, namely, a $1 \%$ loss of the optimal income occurred from the income maximizing solution (THB 11,463) to reduce risk by $4.7 \%$. Third, according to Kaiser and Messer (2012), risk in agriculture can be lowered by two strategies: shifting from the riskiest crop to the less risky crop or diversifying the farm plan rather than relying on only one crop. Diversification is considered to be a riskreducing technique as a combination between the integrated Nanglae and integrated Phulae that have negative co-variances can help to stabilize farm income by lowering aggregate risk.

\section{Conclusion}

The integration of economic performances and environmental impacts allows a wide range of system changes to be assessed and compared. This study modeled the tradeoff between achieving the financial objective (profit maximizing) under risk and the environmental impact indicator associated with pineapple production systems in the northern region of Thailand. Two farming systems were compared and consequently, a sustainable farm model was constructed using farm survey data to assist farmers' decision making. The overall results of LCA revealed that, on a per-hectare basis, the conventional pineapple farming of both cultivars was less environmentally friendly than the integrated farming. The practice had higher environmental impact in all categories mainly related to the use of chemical fertilizers, particularly $\mathrm{N}$-fertilizer. Considering the economic performance of the production, pineapples produced by the integrated farming practice had higher EE than the conventional practice in the same season. In spite of lower fruit yields, the integrated practice produced a higher net income due to high quality of fruits and selling prices coupled with less environmental impact that led to relatively high EE. The results affirmed that EE is closely associated with economic outcome and market prices, indicating that consumers' decisions can play an important role in promoting sustainable agricultural production systems. In this case study, the production of Phulae pineapple by the integrated farming system that can be harvested twice a year was the most preferable choice for farmers from the income-maximizing and EE perspectives. 
On the supply side, the volatility of market prices is a key factor to be considered in farm decisions. Farmers may encounter risk in a wide range of dimensions such as production, price, and finance. In this study, elements of production and market risk in terms of variability of selling prices were captured. Profit maximizing result from the baseline LP was associated with risk-neutral solutions, while QRP was applied to provide a set of farm plans that are efficient for risk-averse farmers. Diversification of the cropping pattern can be an effective strategy to reduce aggregated income risk. The new farm plans were suggested to be diversified by switching to the integrated Nanglae that are negatively correlated with the integrated Phulae in both seasons. Thus, a tradeoff between risk and income occurred. The results from the SFM incorporated with QRP were likely to be useful in assisting risk-averse decision makers to deal with choices and tradeoffs associated with risk-efficient farm plans. With regard to policy implications, a market-based mechanism considering environmental impacts as negative externalities under the "polluter pays" principle may be introduced. This strategy would include impact costs or costs to society that are not currently accounted for in decision making. In addition, government intervention in the form of positive incentive, e.g., tax reduction, credit subsidy, and low-interest loan, could play a significant role in promoting sustainable farms.

This study represents the initial stage of farm-level planning on pineapple production in Thailand based on EE and income risk. The results of this study can be a useful reference in sustainable farm planning and aiding decision-making for consumers in sustainable product consumption. However, due to certain limitations of the current study, future investigations are needed to fill data gaps. First, this study focused on only one production area that could not be represented in regional or country-based cases. Therefore, more extensive data from larger samples are needed. Second, the nature of agricultural activities (e.g., growing length, crop yields, and field operations) is dependent on climatic conditions. Future study should address effects of different climatic scenarios on the modeling results. Moreover, as the sustainable farm models were based on the course of one year (a single-period model), a multi-period model should be developed to study the long-term effects of economic and environmental factors on the farm activities. Besides economic and environmental indicators, social indicators such as physical work strain, labor income, local employment, and education level should be included in the sustainability assessment.

Acknowledgements. The authors are grateful to the National Science and Technology Development Agency for financial support (Project Code: FDA-CO-2561-5672-TH) and the pineapple growers in Nanglae sub-district in Chiang Rai who provided useful data for this study.

\section{REFERENCES}

[1] Anderson, J. R., Dillon, J. L. (1992): Risk analysis in dryland farming system. - FAO, Rome, Italy.

[2] Carvalho, H., Govindan, K., Azevedo, S. G., Cruz-Machado, V. (2017): Modelling green and lean supply chains: an eco-efficiency perspective. - Resources, Conservation and Recycling 120: 75-87.

[3] Chiet, C. H., Zulkifii, R. M., Hidayat, T., Yaakob, H. (2014): Bioactive compounds and antioxidant activity analysis of Malaysian pineapple cultivars. - In: Proceedings on $4^{\text {th }}$ 
International Conference on Mathematics and Natural Sciences (ICMNS 2012), Bandung, Indonesia, Nov 8-9, 2012, pp. 398-399.

[4] Colman, D., Young, T. (1989): Principles of agricultural economics: markets and prices in less developed countries. - The University Press, Cambridge, UK.

[5] Darnaudery, M., Fournier, P., Lechaudel, M. (2018): Low-input pineapple crops with high quality fruit: promising impacts of locally integrated and organic fertilization compared to chemical fertilisers. - Experimental Agriculture 54(2): 286-302.

[6] Department of Agriculture (of Thailand) (2015): Handbook for organic fertilizer (in Thai). - The Agricultural Cooperative Federation of Thailand, Bangkok, Thailand.

[7] FAOSTAT (2020): http://www.fao.org/faostat/en/\#data/QC.

[8] Ferreina, E. A., Siqueira, H. E., Boas, E. V. V., Hermes, V. S., de Oliveira Rios, A. (2016): Bioactive compounds and antioxidant activity of pineapple fruit of different cultivar. - Revista Brasileira de Fruticultura 38(3): 1-7.

[9] Goedkoop, M., Heijungs, R., Huijbergts, M., de Schryver, A., Struijs, J., van Zelm, R. (2013): ReCiPe 2008. A life cycle assessment method which comprises harmonized category indicators at the midpoint and the endpoint level. - National Institute for Public Health and the Environment, Netherlands.

[10] Greendelta (2018): OpenLCA (software). - http://www.openlca.org/.

[11] Hardaker, J. B., Lien, G., Anderson, J. R., Huirne, R. (2015): Coping with risk in agriculture, third edition: applied decision analysis. - CABI Publishing, Wallingford, UK.

[12] Hazell, P. B. R., Norton, R. D. (1986): Mathematical programming for economic analysis in agriculture. - Macmillan, New York, USA.

[13] Hossain, S., Hashim, N., Mustapha, N., Chen, L. T. (2002): A quadratic application in farm planning under uncertainty. - International Journal of Social Economics 29(4): 282298.

[14] Kaiser, H. M., Messer, K. D. (2012): Mathematical programming for agricultural environmental and resource economics. - John Wiley \& Sons Inc, USA.

[15] Kleeman, L. (2011): Organic pineapple farming in Ghana - a good choice for smallholders. - Working paper No. 1671, Kiel Institute for the World Economy, Kiel, Germany.

[16] Komarek, A. M., De Pinto, A., Smith, V. H. (2020): A review of types of risks in agriculture: What we know and what we need to know. - Agricultural Systems 178: 102738.

[17] Liu, K. F.-R., Kuo, J.-Y., Chang, Y.-H., Liang, H.-H. (2016): Optimization of life cycle assessment-based eco-efficiency. - International Journal of Environmental Science and Development 7(3): 211-215.

[18] Markowitz, H. (1959): Portfolio selection; efficient diversifications of investments. John Wiley \& Sons Inc, New York, USA.

[19] Meuwissen, M. P. M., Hardaker, J. B., Huirne, R. B. M., Dijkhuizen, A. A. (2001): Sharing risks in agriculture; principles and empirical results. - NJAS-Wageningen Journal of Life Sciences 49(4): 343-356.

[20] Mungkung, R., Pengthamkeerati, P., Chaichana, R., Watcharothai, S., Kitpakornsanti, K., Tapananont, S. (2019): Life cycle assessment of Thai organic Hom Mali rice to evaluate the climate change, water use and biodiversity impacts. - Journal of Cleaner Production 211: 687-694.

[21] Oonkasem, P., Phrommarat, B., Buawech, D. (2019): Life cycle of Nanglae pineapple production. - In: Proceedings on the $5^{\text {th }}$ EnvironmentalAsia International Conference, Chiang Mai, Thailand, June, 13-15, 2019, IV114-IV126.

[22] Phungrassami, H., Usubharatana, P. (2015): Life cycle assessment and eco-efficiency of para-rubber wood production in Thailand. - Polish Journal of Environmental Studies 24(5): 2113-2126. 
[23] Popluechai, S., Onto, S., Eungwanichayapant, P. D. (2007): Relationships between some Thai cultivars of pineapple (Ananas comosus) revealed by RAPD analysis. Songklanakarin Journal of Science and Technology 29(6): 1491-1497.

[24] Rae, A. N. (1994): Agricultural Management Economics: Activity Analysis and Decision Making. - CABI, Oxfordshire, UK.

[25] Ramsden, S. J., Wilson, P., Phrommarat, B. (2017): Integrating economic and environmental impact analysis: the case of rice-based farming in northern Thailand. Agricultural Systems 157: 1-10.

[26] Robertson, M. J., Panell, D., Chalak, M. (2012): Whole-farm models: a review of recent approaches. - Australasian Farm Business Management Journal 9(2): 1-14.

[27] Rosa, F., Taverna, M., Nassivera, F., Iseppi, L. (2019): Farm/crop portfolio simulations under variable risk: a case study from Italy. - Agricultural and Food Economics 7: 8.

[28] Silalertruksa, T., Gheewala, S. H., Pongpat, P. (2015): Sustainability assessment of sugarcane biorefinery and molasses ethanol production in Thailand using eco-efficiency indicator. - Applied Energy 160: 603-609.

[29] Suk-ueng, K., Chantima, K., Prasertsin, T. (2019): Satellite remote sensing for agricultural mapping at Nanglae sub-district, Muang District, Chiang Rai province. - In: proceedings on the $5^{\text {th }}$ EnvironmentalAsia International Conference, 13-15 June 2019, Chiang Mai, Thailand. Thai Society of Higher Education Institute on Environment, II104II114.

[30] Sulewski, P., Kłoczko-Gajewska, A. (2014): Farmers' risk perception, risk aversion and strategies to cope with production risk: and empirical study from Poland. - Studies in Agricultural Economics 116: 140-147.

[31] Thanawong, K., Perret, S. R., Basset-Mens, C. (2014): Eco-efficiency of paddy rice production in northeastern Thailand: a comparison of rain-fed and irrigated cropping systems. - Journal of Cleaner Production 73: 204-217.

[32] United Nations Economic and Social Commission for Asia and the Pacific (2009): Ecoefficiency indicators: measuring resource-use efficiency and the impact of economic activities on the environment. - United Nations publication, Bangkok, Thailand.

[33] Usubharatana, P., Phungrassami, H. (2017): Evaluation of opportunities to reduce the carbon footprint of fresh and canned pineapple processing in central Thailand. - Polish Journal of Environmental Studies 26(4): 1725-1735. 